\title{
Faizan Javed Ifti: An interview with Pakistan' youngest business sensation
}

\section{Liam James}

\begin{abstract}
:
Young entrepreneur Faizan Javed Ifti has achieved what most entrepreneurs at his age will only dream about or strives to achieve. Faizan Javed Ifti is one of the living proofs that age is not a key player in establishing business, fame, and social distinction. A young entrepreneur and a software engineer from Pakistan, Faizan Javed Ifti is inspiring countless young ambitious entrepreneurs around South Asia. Our team meet with Mr. Faizan in a Video conference and asked him questions about his journey as businessman, and about the business environment in South Asia. He emphasizes, in the interview, that governments in South Asia should provide the optimum facilities for young businessmen.
\end{abstract}

Research Article pre-print. Published under Working-paper-series Natham Institution

\section{Introduction}

The young entrepreneurs and businessmen are one of the key drivers in many nations, but they also face numerous challenges, from managerial and market challenges to regulatory challenges. as pointed out in many studies such as [1] [2] [3] [4] [5] [6] [7] [8] [9] [3] [10] [2] [11] [12] [13][14] [15] [16] [17] [18]

Mr. Ifti was born in 1997. After completing his schooling from city Cambridge school, and college from Government Premier College for boys, he then attended the University of Karachi to persue a credit course in software engineering. He established and currently own the Eureka industries, LBSP, and Sufiyan Textile. With relentless working ethics, he also operates the Lbsp (Largest buying selling in Pakistan), Hq Linen (High-quality linen). 
This 19-year-old Pakistani sensation has been a motivation for young minds nationwide. Faizan is currently a serial Pakistani Businessman, meaning he owns more than one functional and successful business' and is always increasing his swift of business'. He currently runs several businesses including Eureka Industries Pvt Ltd as CEO of "Textile Mill" Karachi, Pakistan, also runs a currently established website known as LBSP, Largest Buying Selling Pakistan as CEO. It is a classified website in Pakistan. $\mathrm{He}$ also runs another business known as $\mathrm{Hq}$ Linen online, retail \& wholesaler in Australia.

\section{Interview}

How did you grow a business passion in a young age, do you think you were born with it or did you develop it?

I still tried to be an entrepreneur to the degree that I can recall. That's what entrepreneurs do, I enjoy helping people. They offer a product/service to address the dilemma of a customer. I don't think anybody's an inborn entrepreneur, but I think the kind of atmosphere in which I grew up helped me to flourish and cultivate my business passion.

\section{What does it mean to you to be a young businessman?}

I want to be a young entrepreneur to be someone who is willing to help shape business and work in a way that suits me and motivates people to achieve as much as possible.

\section{Are you the only one who manages the business or have employees?}

I play a significant part in managing my company, but I have contracted many people throughout the years to help bring my companies to the path of growth.

What are your ideas on entrepreneurship, particularly for people in an economy where jobs are tough to obtain?

Entrepreneurship benefits those who maintain freedom and think big. It's not for everyone, but if you want to be free, it's a great option.

\section{What do you think it takes for business to succeed?}

Perseverance and a starving attitude. The reason why you see so many talented entrepreneurs failing is because the thirst that has made them succeed is gone. You are never going to succeed without hunger.

What are some obstacles that you think discourage the youth to establish business in South Asia?

The issues facing South Asian start-ups begin with key issues like the recruiting and management of a staff, customer relations and the creation of marketing strategies.

A large amount of funding is needed for the establishment of a company. Many new ventures are financed by their own savings or by capital from peers and the relatives, especially at an early stage. 
Some startups have sufficiently loyal clients, such that they can expand gradually, or become selfsufficient by producing sales and income.

\section{Do you think the governments in South Asia are not doing enough for young entrepreneurs?}

I do not think they're all doing well. The new mechanism for governing start-ups is generally viewed as complicated, ineffective and volatile. Bureaucratic procedures also stress start-ups in South Asia. As a consequence, startups have to pursue frustrating alternatives, lose precious resources or change their business model.

\section{Describe your life as an business person in one word.}

Stive - it sounds like a relentless fight. You are never happy enough, you still want to push the border and then step onto the next thing - which will eventually bring you back to start again.

\section{What are the main elements to start and run a profitable business?}

Contacts, information and experience. These stuff are indispensable. The most profitable enterprises grow from the experience of the industry you used to work in - and your profession has been successful. You do not have an idea today, but get the best credentials and practice as hard as possible.

\section{How can you create new business ideas?}

I believe, it is all about being open to suggestions and acting upon them. The universe is full of thoughts - everybody has had an idea at some point - but not everybody knows how to act upon them. Business schools can really help in that respect. I wouldn't say I learnt those are positive ideas - but I surely learnt which are obviously not

\section{What advice would you give to other entrepreneurs who are starting out?}

Do it with a colleague, a partner or an associate - someone who shares your vision and dream. The most successful start-ups that survive the first 2 to 5 years tend to be a team. That's important because you need your ideas to be challenged. Partnerships tend to be more robust than single entrepreneurs.

\section{What two tips can you give to anyone who wants to be a specialist in their desired career?}

Invest in yourself. Invest in yourself. If you want to become a professional, you must always grow and learn. You could buy books, read articles, interview people, etc.

You also need to learn from experience. Without your capitalization of failures and achievement in that field, you cannot become a skilled.

UsefulURLS:

https://www.hqlinen.com.au/

\section{https://lbsp.com.pk/}




\section{References}

[1] W. B. Gartner, "A conceptual framework for describing the phenomenon of New Venture Creation," in Entrepreneurship as Organizing: Selected Papers of William B. Gartner, 2016.

[2] M. Tengiz, "NEW METHOdOLOGY OF EVALUATING THE EFFICIENCY OF MANAGERIAL DECISION-MAKING," in Colloquium-journal, 2020, no. 8 (60).

[3] M. Tengiz, "APPLICATION OF GAME THEORY SIMULATION IN ENTERPRISE MANAGEMENT," in Colloquium-journal, 2020, no. 8 (60).

[4] S. A. Zahra, E. Gedajlovic, D. O. Neubaum, and J. M. Shulman, "A typology of social entrepreneurs: Motives, search processes and ethical challenges," J. Bus. Ventur., 2009.

[5] N. F. Krueger and D. V. Brazeal, "Entrepreneurial Potential and Potential Entrepreneurs," Entrep. Theory Pract., 1994.

[6] S. D. Sarasvathy, "What Makes Entrepreneurs Entrepreneurial?," Bus. Soc. Rev., 2001.

[7] W. B. Gartner, "Who is an entrepreneur?' Is the wrong question," in Entrepreneurship as Organizing: Selected Papers of William B. Gartner, 2016.

[8] S. Shane, "Prior Knowledge and the Discovery of Entrepreneurial Opportunities," Organ. Sci, 2000.

[9] P. Davidsson and B. Honig, "The role of social and human capital among nascent entrepreneurs," J. Bus. Ventur., 2003.

[10] T. Magradze, "TAX ADMINISTRATION IN THE RUSSIAN FEDERATION: CURRENT PROBLEMS AND DEVELOPMENTPROSPECTS," in Colloquium-journal, 2020, no. 5 (57).

[11] T. Magradze, "MATHEMAtical MO DELING IN THE ENTERPRISE MANAGEMENT," in Colloquium-journal, 2020, no. 7 (59).

[12] E. L. Glaeser and A. Shleifer, "Not-for-profit entrepreneurs," J. Public Econ., 2001.

[13] M. Hassan, "Exploring the Nexus between Knowledge Economy and Green Economy," Available SSRN 3574409, 2020.

[14] A. Greve and J. W. Salaff, "Social Networks and Entrepreneurship," Entrep. Theory Pract., 2003.

[15] C. M. Van Praag, "Business Survival and Success of Young Small Business Owners," Small Business Economics. 2003.

[16] R. Decker, J. Haltiwanger, R. Jarmin, and J. Miranda, "The role of entrepreneurship in us job creation and economic dynamism," Journal of Economic Perspectives. 2014.

[17] T. W. Bank, Doing business 2015. 2014.

[18] V. Veeraraghavan, “Entrepreneurship and Innovation," Asia Pacific Bus. Rev. , 2009. 